\title{
Finding Safe and Cheap Exchanges to Hydrogen Cyanamide on "Flame Seedless" grapevines
}

\author{
Mohamed E. A. El-Sayed ${ }^{1}$ and Sherin A. Mahfouze ${ }^{2}$ \\ ${ }^{1}$ Viticulture Department, Horticulture Research Institute, Agricultural Research Center, Giza, \\ Egypt. \\ ${ }^{2}$ National Research Centre, Genetic Engineering and Biotechnology Research Division, \\ Genetics and Cytology Department, Dokki, 12622, Egypt.
}

\begin{abstract}
This study was carried out to study the effect of safe alternatives as compared to hydrogen cyanamide on breaking dormancy of" Flame seedless" grapevines. The vines were subjected the following spray treatments; control, garlic oil, hydrogen peroxide, copper sulphate, zinc sulphate, boric acid and hydrogen cyanamide in the second week of January. All treatments except zinc sulphate in the second season had higher bud burst $\%$ than control. The results also showed that copper sulphate and hydrogen cyanamide applications significantly increased bud burst \% than other treatments in both seasons. In both seasons, hydrogen cyanamide gave higher yield and juice volume than the rest treatments, except hydrogen peroxide for yield in the second season. Hydrogen cyanamide and zinc sulphate applications increased cluster weight in the second season only. Weight and size of 100 berries were significantly increased by copper and zinc sulphate and hydrogen cyanamide. In the first season, copper sulphate and hydrogen peroxide treatments increased berry length and diameter. On the other hand, the results showed that there were non significant differences among tested treatments concerning berry length and diameter in the second season and L/D ratio in both seasons. In the first season, the highest percentage of T.S.S was obtained by vines sprayed with garlic oil. In the second season, T.S.S\% was not affected by different applications. Data showed that zinc, copper sulphate and garlic oil significantly decreased acidity in the second season. The results in both seasons indicated that garlic oil, copper and zinc sulphate applications lead to increase T.S.S/acid ratio. The data in both seasons indicated that anthocyanin content was increased by garlic oil treatment. In both seasons, garlic oil and hydrogen cyanamide considerable increased shoot length. Hydrogen peroxide caused increase in fruitfulness $\%$, number of clusters and leaves in both seasons. Generally, there were non significant differences among used treatments concerning peroxidase activity. Catalase activity was highly increased with bud burst which appeared as achromatic zone with high intensity in all treatments, except boric acid in the first season and copper, zinc sulphate and hydrogen cyanamide treatments in the second season.
\end{abstract}

Key words: Grape, Hydrogen cyanamide, Copper sulphate, Garlic oil, Peroxidase, Catalase.

\section{INTRODUCTION}

Red table grape "Flame Seedless" is earlyseason grape variety in Egypt with a firm, crispy texture and sweet, natural taste and has the ability of exporting and marketing. In warm winter regions, lack of sufficient chilling during the winter is a major obstacle for the commercial production of table grapes. This is due to the symptoms of prolonged dormancy that often, include delayed and low percentages of bud burst, delayed and protracted flowering season, irregular ripening, decreased yields, quick decline in growth vigor and early senescence of the vines (Dokoozlian and Williams, 1995). To overcome this problem, farmers apply hydrogen cyanamide $\left(\mathrm{H}_{2} \mathrm{C}_{2}\right)$ on the vine immediately following pruning. Hydrogen cyanamide advances early bud break and improves the bud break uniformity of grapevines (Lavee et al., 1984; Mc Coll., 1986).

Hydrogen cyanamide is a highly toxic and is classified by the Environmental Protection Agency of the United States of America in the highest category of toxicity (Category I). Moreover, the record of this product is under review by the European Union (Settimi et al., 2005). Nevertheless, this compound is not authorized for use in organic agriculture. Kubota et al. (2000) found that garlic oil and garlic paste gave earlier budbreak than in the control. Kuroda et al. (2005) reported that hydrogen peroxide is effective in breaking endodormancy in flower buds of the Japanese pear. Fulford (1970) found that spraying supr buds of apple with copper sulphate caused budbreak into a second flush of growth and eventually to form a new resting bud. Diaz et al.(1987) reported that chemical defoliation of peach by zinc sulphate and of apple by copper sulphate, enhanced bud opening. Jojoba oil, candida tennis and microelements mixture could partially replace hydrogen cyanamide in getting up earlier bud sprouting (Abd el-Latife, 2007). Smith (2006) found that high concentration of boron applied to grapevine pruning wounds resulted in the highest percent budbreak of the basal node. Accordingly, the aim of the present study is to determine the efficacy for new alternatives as compared to hydrogen cyanamide on breaking dormancy, yield and fruit quality of Flame Seedless grapevines.

\section{MATERIALS AND METHODS}

The experiment was carried out during two 
successive growing seasons, 2010/2011 in Agricultural Alexandria Cooperation, Nubaria, Elbehera. Flame Seedless grapevines were seven years old, uniform, grown in calcareous soil on wire trellis system and under drip irrigation. They were planted at $3 \times 2 \mathrm{~m}$ spacing. All vines were subjected to the cultural practices commonly used in this farm. The experimental design was the randomized complete blocks with three replications per treatment and one vine replicate. The vines were subjected to foliar spray treatments in the second week of January as the follows:

Control (water only spray)

Garlic oil at 3\%

Hydrogen peroxide $\left(\mathrm{H}_{2} \mathrm{O}_{2}\right)$ at $3 \%$

Copper sulphate at $1 \%$

Zinc sulphate at $1 \%$

Boric acid at $1 \%$

Hydrogen cyanamide (Dormex ) at $4 \%$

The beginning of budburst was recorded when five buds per vine were opened i.e. when leaves tips emerged from the buds. Number of bursted out buds/vine was recorded, then the percentage of bud burst was calculated by dividing number of bud burst per vine by the total number of buds per vine left at pruning (three-day intervals along the bursting period). Besides, number of fruitfulness buds were counted, then the percentage of fruitfulness was calculated by dividing No.of fruitfulness buds per vine by No. of bursted buds. At growth cessation, the following vegetative growth parameters were carried out on four shoots/vine, average shoot length $(\mathrm{cm})$ and average number of leaves / shoot. The harvest date was 18 and 14 June in 2010 and 2011 respectively when the checked berries reached maturity stage $(16 \%-17 \%)$ according to Tourkey et al (1995). The total yield was recorded per vine and expressed as No. of clusters and $\mathrm{kg} / \mathrm{vine}$. Random samples of five clusters/vine were harvested to determine the physical and chemical characteristics of berries. Physical parameters (cluster weight, weight and volume of 100 berries, juice volume of 100 berries, berry length (L) and diameter (D), and average berry shape index (L/D). Chemical properties; total soluble solids were measured by a Refractometer. Titratable acidity using $0.1 \mathrm{~N} \quad \mathrm{NaOH}$ were determined according to A.O.A.C (1990). T.S.S/acid ratio was also calculated. Anthocyanin in berries (mg/100 $\mathrm{g}$ ) was determined according to Husia et al. (1965).

Extraction of peroxidase (POD) and catalase (CAT) isozymes was carried out before spraying application (initial bud dormancy) and at 50\% bud burst. Native-polyacrylamide gel electrophoresis (Native-PAGE) was conducted to identify isozyme variations among treatments and healthy control using peroxidase (POD) and catalase (CAT) isozymes according to Stegemann et al. (1985) and Woodbury et al. (1971). The obtained data were statistically analyzed according to Snedecor and Cochran. (1980).

\section{RESULTS AND DISCUSSION}

Bud burst percentage: The results in both seasons indicated that all treatments, except zinc sulphate in the second season increased bud burst than control and that copper sulphate and hydrogen cyanamide significantly increased bud burst percentage as compared with the remaining treatments. Bud burst $\%$ was remarkable increased with advancing dates. Regarding the interaction between treatments and periods on bud burst \%, the highest percentage of bud burst \% was obtained by spraying vines with copper sulphate followed by spraying with hydrogen cyanamide at the end of bud burst with significant difference in the second season. However, control at the first period recorded the lowest value in both seasons (Tables 1 and 2). These results were supported by Fulford (1970) and Diaz et al., (1987). They reported that spraying buds of apple with copper sulphate caused bud break and enhanced bud opening. This effect may be due inhibiting of catalase molecules by copper sulphate. This means that copper sulphate will stop the catalase from breaking down the hydrogen peroxide by binding with the catalase molecules not on their active site which will distort the shape of the active site (Jones et al., 2000).

Table 1: Effect of some treatments on bud burst percentage of Flame Seedless grapevines in 2010 season.

\begin{tabular}{lccccccc}
\hline \multicolumn{1}{c}{ Dates } & $\mathbf{1 1 / 2}$ & $\mathbf{1 4 / 2}$ & $\mathbf{1 7 / 2}$ & $\mathbf{2 0 / 2}$ & $\mathbf{2 3 / 2}$ & $\mathbf{2 6 / 2}$ & Mean \\
\cline { 1 - 7 } Treatments & & & & & & & \\
Control & .84 & 5.12 & 17.03 & 23.48 & 36.70 & 43.53 & 21.11 \\
Hydrogen peroxide & 13.13 & 19.47 & 31.67 & 41.55 & 51.49 & 61.64 & 36.49 \\
Boric acid & 10.48 & 16.44 & 28.52 & 49.06 & 55.03 & 65.43 & 37.49 \\
Copper sulphate & 25.01 & 32.46 & 54.56 & 69.38 & 79.94 & 88.33 & 58.28 \\
Hydrogen cyanamide & 25.53 & 34.19 & 48.61 & 63.23 & 64.72 & 85.81 & 53.68 \\
Garlic oil & 9.40 & 13.56 & 24.25 & 44.07 & 56.34 & 66.94 & 35.76 \\
Zinc sulphate & 2.35 & 5.47 & 9.89 & 29.44 & 48.49 & 58.95 & 25.76 \\
\hline Mean & 12.39 & 18.10 & 30.65 & 45.74 & 56.10 & 67.23 & \\
\hline
\end{tabular}

L.S.D.05 Date 1.60, Treat 3.99, Date * Treat 9.82 
Table 2: Effect of some treatments on bud burst percentage of Flame Seedless grapevines in 2011 season.

\begin{tabular}{|c|c|c|c|c|c|c|c|}
\hline $\begin{array}{ll}\text { Treatments } & \text { Dates } \\
\end{array}$ & $7 / 2$ & $10 / 2$ & $13 / 2$ & $16 / 2$ & $19 / 2$ & $22 / 2$ & Mean \\
\hline Control & 8.88 & 17.01 & 34.94 & 48.38 & 66.75 & 72.61 & 41.43 \\
\hline Hydrogen peroxide & 20.21 & 28.19 & 38.70 & 47.58 & 58.90 & 73.75 & 44.55 \\
\hline Boric acid & 21.15 & 29.67 & 44.62 & 63.49 & 70.84 & 80.64 & 51.73 \\
\hline Copper sulphate & 30.94 & 37.97 & 61.23 & 75.87 & 95.28 & 98.81 & 66.68 \\
\hline Hydrogen cyanamide & 38.30 & 47.69 & 58.06 & 69.60 & 78.56 & 90.11 & 63.72 \\
\hline Garlic oil & 15.87 & 22.14 & 36.65 & 58.48 & 74.49 & 84.79 & 48.73 \\
\hline Zinc sulphate & 8.95 & 13.68 & 27.40 & 48.70 & 72.06 & 79.73 & 41.75 \\
\hline Mean & 20.61 & 28.05 & 43.08 & 58.87 & 73.84 & 82.92 & \\
\hline
\end{tabular}

L.S.D.05 Date 1.96, Treat 2.39, Date * Treat 5.88

Moreover, Dhankhar (2011) found that activity of peroxidase enzyme got increased under the combined zinc and copper metals whereas catalase activity got declined in comparison to control. Shulman et al. (1986) observed that in grapevines buds, application of hydrogen cyanamide resulted in a reduction of catalase activity, while peroxidase activity was generally unchanged. Therefore, it is suggested that hydrogen cyanamide is involved in breaking dormancy by reducing catalase activity.

Shoot length, leaves number and fruitfulness \%: In both seasons, boric acid, garlic oil and hydrogen cyanamide considerably increased shoot length as compared with the control. The data also in both seasons indicated that leaves number was increased by hydrogen peroxide in comparison with the check treatment with significant difference in the first season only, Table (3). In both seasons, the results indicated that hydrogen peroxide had significantly the highest fruitfulness $\%$ as compared other treatments, Table (3). Similar results were observed by Hassan (2008) and Shaddad (2010) who recorded that spraying hydrogen cyanamide improved main shoot length and number of leaves per shoot compared to the check treatment of "Red Roomy" and "Superior" grapevines. Garlic oil (Allium sulphur compounds) is antioxidant. It has been reported that antioxidants can enhance the sugar accumulation (Jordao and Correia, 2012). On the other hand, Jana and Das (2013) reported that pear treated with hydrogen peroxide at $10 \%$ gave higher final fruit set $\%$ than control.

Yield and number of clusters: In both seasons, hydrogen cyanamide and hydrogen peroxide gave higher yield than control, Table (4). Also, In both seasons, the results showed that hydrogen peroxide had significantly the highest number of clusters in both seasons, Table (4) The above mentioned results are nearly similar to those obtained by Ahmed and El-Sese (2004), Abbas et al.(1999); El-Halaby (2006) and Eshghi et al. (2010) they reported that hydrogen cyanamide effectively improved the yield of grapevines. This effect may be due to production of greater number of shoots per spur and a higher number of bunches per shoot on spur by hydrogen cyanamide (George and Nissen, 1990). Besides, Jana and Das (2013) reported that pear treated with hydrogen peroxide at $10 \%$ gave higher final fruit set $\%$ than control.

Cluster weight: In the first season, all treatments remarkably increased cluster weight as compared with the control. In the second season, cluster weight was not significantly affected by treatments, Table (4).

Table 3: Effect of treatments on shoot length, leaves numbers and fruitfulness \% of Flame Seedless grapevines in 2010 and 2011 seasons.

\begin{tabular}{lcccccc}
\hline \multirow{2}{*}{ Treatments } & Parameters & \multicolumn{2}{c}{ Shoot length $(\mathbf{c m})$} & \multicolumn{2}{c}{ Leaves numbers } & \multicolumn{2}{c}{ Fruitfulness \% } \\
\cline { 2 - 7 } Control & $\mathbf{2 0 1 0}$ & $\mathbf{2 0 1 1}$ & $\mathbf{2 0 1 0}$ & $\mathbf{2 0 1 1}$ & $\mathbf{2 0 1 0}$ & $\mathbf{2 0 1 1}$ \\
Hydrogen peroxide & 147.50 & 99.33 & 32.50 & 24.66 & 39.06 & 30.34 \\
Boric acid & 142.33 & 129.17 & 46.25 & 38.16 & 69.88 & 62.67 \\
Copper sulphate & 185.00 & 142.67 & 42.00 & 27.50 & 67.41 & 45.00 \\
Hydrogen cyanamide & 151.75 & 111.67 & 32.25 & 23.00 & 65.41 & 47.07 \\
Garlic oil & 219.50 & 147.83 & 24.50 & 33.50 & 64.56 & 48.05 \\
Zinc sulphate & 222.50 & 167.50 & 36.75 & 26.00 & 57.61 & 31.24 \\
L.S.D.05 & 172.50 & 128.00 & 35.00 & 22.50 & 67.00 & 42.65 \\
\hline
\end{tabular}


Table 4: Effect of treatments on yield, cluster weight and weight of 100 berries of Flame Seedless grapevines in 2010 and 2011 seasons.

\begin{tabular}{lcccccc}
\hline & Yield & (Kg) & \multicolumn{2}{c}{ Cluster weight (g) } & \multicolumn{2}{c}{ No.of clusters } \\
\cline { 2 - 7 } Treatments & $\mathbf{2 0 1 0}$ & $\mathbf{2 0 1 1}$ & $\mathbf{2 0 1 0}$ & $\mathbf{2 0 1 1}$ & $\mathbf{2 0 1 0}$ & $\mathbf{2 0 1 1}$ \\
\hline Control & 17.93 & 16.86 & 564.53 & 487.70 & 31.33 & 27.00 \\
Hydrogen peroxide & 25.12 & 26.58 & 738.83 & 572.43 & 48.00 & 40.00 \\
Boric acid & 18.45 & 16.86 & 764.18 & 642.57 & 34.66 & 32.00 \\
Copper sulphate & 19.13 & 23.39 & 704.94 & 573.37 & 35.00 & 33.33 \\
Hydrogen cyanamide & 27.06 & 25.27 & 859.35 & 680.15 & 38.33 & 30.00 \\
Garlic oil & 20.25 & 22.74 & 675.34 & 504.45 & 40.00 & 32.00 \\
Zinc sulphate & 17.94 & 18.31 & 839.58 & 509.72 & 39.00 & 33.00 \\
\hline L.S.D ..05 & 6.42 & 5.72 & 109.41 & N.S. & 8.16 & 6.89 \\
\hline
\end{tabular}

The obtained results are in partial agreement with Ahmed and El-Sese (2004), Abbas et al.(1999) and Nikkhuh et al. (2013) who observed that foliar application of hydrogen cyanamide and zinc sulphate considerable increased cluster weight of grapevines, due to increasing berry set and berry weight of grape (Faissal et al., 1997; Abdel Hameed, 1997; Abbas et al., 1999). On the other hand, Farag (2006) found that copper and zinc sulphate did not significantly affect fruit weight or length of "Thompson seedless"grape. OR et al. (1999) found that cluster weight of the control vines was similar to that of hydrogen cyanamide treated vines from the late application date.

Weight and size of 100 berries: In the first season, hydrogen cyanamide recorded the highest weight and size of 100 berries while control gave the lowest value. In the second season, copper and zinc sulphate significantly increased weight and size of 100 berries as compared with control and hydrogen peroxide treatments and it did not significantly differ from hydrogen cyanamide application, Table (5). Similar results were observed by Ahmed and El-Sese (2004), Abbas et al.,(1999), and Nikkhah et al.(2013), they reported that hydrogen cyanamide and micronutrients led to increase berry weight and size of grapevines. Rogiers et al. (2006) observed that the rate of gain in berry weight varied throughout development, trends in elements concentration were often very different from the trends in elements accumulation per berry. The concentration of potassium, boron and copper continued to increase throughout development. It may be, therefore, that accumulation of sugars into the berry and uptake of water, especially after veraison results in berry weight increase. On the other hand, zinc concentration declined after veraison. Also, the decrease in concentration of zinc could be attributing directly to the gains in berry fresh weight where it is involved in the synthesis of phytohormones.

Juice volume of 100 berries: In both seasons results indicated that hydrogen cyanamide had the greatest juice volume, Table (5). Hassan (2008) and Shaddad (2010) reported that hydrogen cyanamide significantly improved physical characters of the berries.

Berry length and diameter and $L / D$ ratio: In the first season, copper sulphate and hydrogen peroxide applications gave higher berry length and diameter than other treatments including control. In the second season, berry length and diameter were not significantly affected by treatments. The data in both seasons also indicated that, there were not significant differences among tested treatments concerning $\mathrm{L} / \mathrm{D}$ ratio, Table (6). These results are in parallel with the findings by Nikkhah et al. (2013) they reported that berry size was increased by micronutrients. However, Farag (2006) found that copper and zinc sulphate did not remarkable affect fruit length of "Thompson seedless" grape.

Table 5: Effect of treatments on some physical properties of Flame Seedless grapevines in 2010 and 2011 seasons.

\begin{tabular}{|c|c|c|c|c|c|c|}
\hline \multirow[b]{2}{*}{ Treatments } & \multicolumn{2}{|c|}{$\begin{array}{l}\text { Weight of } 100 \text { berries } \\
\text { (g) }\end{array}$} & \multicolumn{2}{|c|}{$\begin{array}{c}\text { Size of } 100 \text { berries } \\
\left(\mathrm{cm}^{3}\right)\end{array}$} & \multicolumn{2}{|c|}{$\begin{array}{l}\text { Juice volume of } 100 \text { berries } \\
\left(\mathrm{cm}^{3}\right)\end{array}$} \\
\hline & 2010 & 2011 & 2010 & 2011 & 2010 & 2011 \\
\hline Control & 329.68 & 295.61 & 313.33 & 284.37 & 305.67 & 240.03 \\
\hline Hydrogen peroxide & 370.70 & 286.28 & 350.00 & 273.33 & 284.52 & 234.59 \\
\hline Boric acid & 366.65 & 314.75 & 350.00 & 300.00 & 314.82 & 257.82 \\
\hline Copper sulphate & 365.70 & 346.63 & 345.00 & 330.00 & 302.40 & 267.88 \\
\hline Hydrogen cyanamide & 397.09 & 329.39 & 380.00 & 313.33 & 346.00 & 351.33 \\
\hline Garlic oil & 336.20 & 303.84 & 320.00 & 293.33 & 235.67 & 242.33 \\
\hline Zinc sulphate & 353.80 & 345.54 & 360.10 & 320.00 & 288.10 & 242.75 \\
\hline L.S.D.05 & 39.51 & 39.34 & 34.67 & 30.14 & 36.84 & 28.66 \\
\hline
\end{tabular}


Chemical properties:

Total soluble solids: In the first season, the highest percentage of total soluble solids was obtained by vines sprayed with garlic oil followed by hydrogen cyanamide. However, control and boric acid treatments gave the lowest values of T.S.S. In the second season, T.S.S were not significantly affected by different applications, Table (7). Shaddad (2010) and Abd El-Wadoud (2010) recorded that application of garlic oil and hydrogen cyanamide increased total soluble solids rather than the check treatment of "Superior and "Flame Seedless" grapevines which was in line with the results of the first season. Besides, Abd El-Razek et al. (2011a) and Abd El-Razek et al. (2013) found that T.S.S of "Canino" apricot and Leconte pear was increased by garlic extract and hydrogen cyanamide treatments compared with the control. On the other hand, Eshghi et al. (2010) reported that hydrogen cyanamide and Volk oil treatments and time of application had little effect on T.S.S of grapes. Powell (1997) observed that hydrogen cyanamide had no significant effect on T.S.S content of mature kiwifruit.

Acidity: Data in Table (7) showed that zinc, copper sulphate and garlic oil significantly decreased acidity as compared with control and hydrogen peroxide applications in the first season and as compared with control and hydrogen cyanamide treatments in the second season. These results are in line with those reported by Farag (2006) who observed that acidity in "Thompson seedless" grape remarkably decreased by zinc sulphate. Besides, Attia (1998) mentioned that reducing acidity of "Red Roomy" cultivar was due to spraying $\mathrm{Zn}$, Fe and $\mathrm{Cu}$ at $0.3 \%$ in sulphate form. Nikkhuh et al. (2013) reported that acidity of grapevines was decreased by foliar application of boron and zinc. This reduction in acidity could be attributed to increasing potassium content due to zinc while potassium interacted with tartaric acid to form potassium bitartrate which has limited solubility (Aktas et al., 2006; Abd-Razeket al., 2011a and Lang, 1983). On the other hand, copper is component of oxidative enzymes used in respiration which caused consumption of acids with consequent decrease in acidity (Al-Shoffe, 2005).

T.S.S/ acid ratio: The data in both seasons showed that garlic oil, copper and zinc sulphate applications gave higher T.S.S/ acid ratio than control, Table(7). These findings seem to be in agreement with those of Marschner (1995) who found that copper plays an important role in, or is a component of oxidation enzymes in chlorophyll synthesis. Besides, zinc is a component of molecular carbonic anhydrides which involve in photosynthesis processes causing increase in the level of solids. Garlic (Allium sulphur compounds) is antioxidant. It has been reported that antioxidants can enhance the sugar accumulation (Jordao and Correia, 2012).

Table 6: Effect of treatments on some physical properties of Flame Seedless grape seedless grapevines in 2010 and 2011 seasons.

\begin{tabular}{|c|c|c|c|c|c|c|}
\hline \multirow{2}{*}{$\begin{array}{c}\text { Parameters } \\
\text { Treatments }\end{array}$} & \multicolumn{2}{|c|}{ Berry length (mm) } & \multicolumn{2}{|c|}{ Berry diameter(mm) } & \multicolumn{2}{|c|}{ Length/Diameter ratio } \\
\hline & 2010 & 2011 & 2010 & 2011 & 2010 & 2011 \\
\hline Control & 17.86 & 17.96 & 16.37 & 16.71 & 1.09 & 1.06 \\
\hline Hydrogen peroxide & 18.39 & 16.89 & 16.27 & 17.63 & 1.04 & 1.03 \\
\hline Boric acid & 17.79 & 16.72 & 16.13 & 17.14 & 1.03 & 1.03 \\
\hline Copper sulphate & 18.68 & 17.08 & 16.78 & 17.88 & 1.01 & 1.04 \\
\hline Hydrogen cyanamide & 17.65 & 17.25 & 16.63 & 17.58 & 1.03 & 1.00 \\
\hline Garlic oil & 17.30 & 16.94 & 15.91 & 16.43 & 1.06 & 1.05 \\
\hline Zinc sulphate & 17.31 & 16.35 & 15.77 & 16.83 & 1.03 & 1.02 \\
\hline L.S.D.05 & 0.45 & N.S & N.S. & 0.57 & N.S & N.S \\
\hline
\end{tabular}

Table 7: Effect of treatments on some chemical properties of Flame Seedless grapevines in 2010 and 2011 seasons.

\begin{tabular}{|c|c|c|c|c|c|c|c|c|}
\hline \multirow{2}{*}{$\begin{array}{l}\text { Parameters } \\
\text { Treatments }\end{array}$} & \multicolumn{2}{|c|}{ T.S.S\% } & \multicolumn{2}{|c|}{ Acidity\% } & \multicolumn{2}{|c|}{ T.S.S/acid ratio } & \multicolumn{2}{|c|}{ Anthocyanin mg/100g } \\
\hline & 2010 & 2011 & 2010 & 2011 & 2010 & 2011 & 2010 & 2011 \\
\hline Control & 15.28 & 16.84 & 0.68 & 0.77 & 23.76 & 21.96 & 1.91 & 3.81 \\
\hline Hydrogen peroxide & 16.55 & 17.40 & 0.67 & 0.72 & 24.57 & 24.00 & 2.44 & 3.67 \\
\hline Boric acid & 15.85 & 17.23 & 0.62 & 0.72 & 25.34 & 23.90 & 2.58 & 7.24 \\
\hline Copper sulphate & 16.19 & 17.33 & 0.59 & 0.65 & 27.43 & 26.66 & 3.07 & 5.33 \\
\hline Hydrogen cyanamide & 16.61 & 17.60 & 0.64 & 0.78 & 25.95 & 22.56 & 2.37 & 4.11 \\
\hline Garlic oil & 16.77 & 18.18 & 0.60 & 0.61 & 27.82 & 29.49 & 3.83 & 7.35 \\
\hline Zinc sulphate & 16.48 & 17.11 & 0.60 & 0.67 & 27.32 & 25.43 & 3.19 & 4.63 \\
\hline L.S.D.05 & 0.87 & N.S & 0.04 & 0.06 & 2.18 & 2.95 & 0.97 & 1.85 \\
\hline
\end{tabular}


Moreover, these results are in parallel with the findings of Shaddad (2010); Abd El-Wadoud (2010);Attia (1998) and Nikkhuh et al. (2013) on grapevines.

Anthocyanin: In the first season, garlic oil induced higher anthocyanin than hydrogen cyanamide and control and it did not significantly differ from zinc and copper sulphate. In the second season, garlic oil and boric acid significantly increased anthocyanin as compared other treatments, Table (7). Abd ElWadoud (2010) observed that garlic oil increased anthocyanin content of "Flame seedless" cultivar as compared with the control. Besides, Kim and Jeong (2001) and Hassan (2008) worked on the effect of natural extracts i.e., garlic oil and onion oil on the berry chemical characteristics of some grape cultivars. Faissal et al. (1997) observed that there was a gradual increase in total anthocyanins of grapes with spraying of zinc and iron. This effect may be due to the role of garlic (Allium sulphur compounds), copper and zinc as sources of antioxidants. Also, there was a positive relationship between the different proanthocyanidin fractions and antioxidant capacity of grape varieties. Furthermore, boron plays a role in the internal regulation of growth by plant hormones and sugar translocation and metabolism. Then, the sugars in skins had close relationship with the anthocyanin (Jordao and Correia, 2012; Nijjar 1985; GonzalezSanjose, 1992).

\section{Peroxidase (POD) isoenzyme:}

POD isozyme was separated by native electrophoresis and monitored for POD activity (Fig. 1). The electrophoretic patterns were characterized by the appearance of two main distinct bands with relative front $(R f)$ of 0.594 and 0.755 (Table 8). Two bands showed differences in the intensity (very dark, dark and faint) among the initial bud dormancy and 50\% bud burst.

POD activity under garlic in both seasons and control in the first season was increased by advancing time from initial bud dormancy to $50 \%$ bud burst. POD activity at zinc in the first season and hydrogen peroxide, copper sulphate, hydrogen cyanamide and control in the second season was decreased by progressing days from initial bud dormancy to $50 \%$ bud burst . POD activity under hydrogen peroxide, copper, boric and hydrogen cyanamide in the first season and boric and zinc in the second season was not affected by advancing days from initial bud dormancy to $50 \%$ budburst.

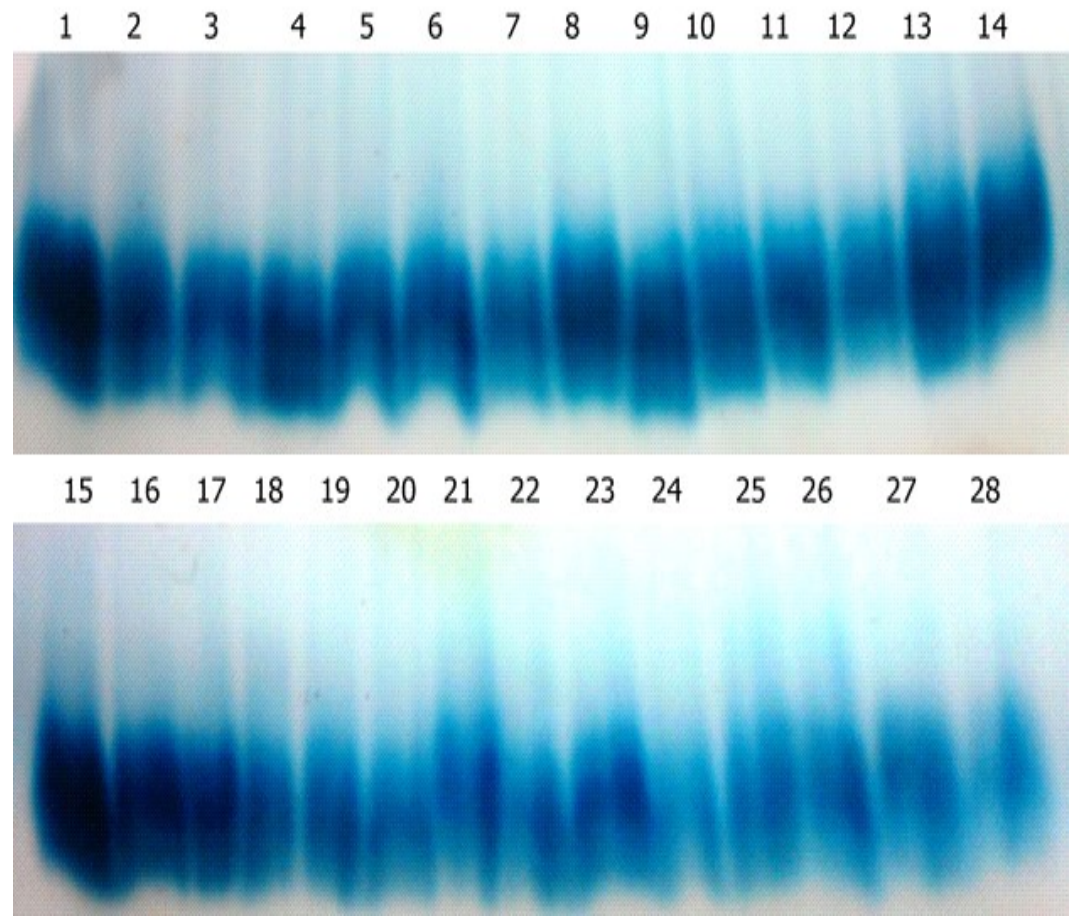

Fig. 1: Native gel stained for activity of POD in grape buds.

Lanes 1- 14 (initial bud dormancy)

Lane 15 (Hydrogen peroxide 2010), lane 16 (Garlic oil 2010), lane 17 (Garlic oil 2011), lane 18 (Hydrogen peroxide 2011), lane 19 (Copper sulphate 2010), lane 20 (Boric acid 2010), lane 21 (Control 2010), lane 22 (Hydrogen cyanamide 2010), lane 23 (Boric acid 2011), lane 24 (Copper sulphate 2011), lane 25 (Zinc sulphate 2010), lane 26 (Zinc sulphate 2011), lane 27 (Hydrogen cyanamide 2011) and lane 28 (Control 2011). 
Table 8: POD profiles of the initial grape buds dormancy and 50\% bud burst in 2010 and 2011 seasons.

Samples 1- 14 (initial bud dormancy)

\begin{tabular}{lcccccccccccccc}
\hline $\boldsymbol{R} \boldsymbol{f}$ & $\mathbf{1}$ & $\mathbf{2}$ & $\mathbf{3}$ & $\mathbf{4}$ & $\mathbf{5}$ & $\mathbf{6}$ & $\mathbf{7}$ & $\mathbf{8}$ & $\mathbf{9}$ & $\mathbf{1 0}$ & $\mathbf{1 1}$ & $\mathbf{1 2}$ & $\mathbf{1 3}$ & $\mathbf{1 4}$ \\
\hline 0.594 & +3 & +2 & +2 & +3 & +2 & +2 & +1 & +2 & +2 & +2 & +2 & +1 & +2 & +2 \\
\hline 0.755 & +3 & +2 & +2 & +3 & +2 & +2 & +1 & +2 & +2 & +2 & +2 & +1 & +2 & +2 \\
\hline
\end{tabular}

\section{Samples 15-28 50\% bud burst}

\section{Table 8: Continued.}

\begin{tabular}{|c|c|c|c|c|c|c|c|c|c|c|c|c|c|c|}
\hline$\underline{R f}$ & 15 & 16 & 17 & 18 & 19 & 20 & 21 & 22 & 23 & 24 & 25 & 26 & 27 & 28 \\
\hline 0.594 & +3 & +3 & +3 & +2 & +2 & +2 & +2 & +2 & +2 & +1 & +1 & +1 & +1 & +1 \\
\hline 0.755 & +3 & +3 & +3 & +2 & +2 & +2 & +2 & +2 & +2 & +1 & +1 & +1 & +1 & +1 \\
\hline
\end{tabular}

POD activity at $50 \%$ bud burst was increased by hydrogen peroxide and garlic oil in both seasons and boric acid in the second season as compared with control. However, POD activity at $50 \%$ was decreased by zinc in the first season as compared the untreated treatment. On the other hand, POD activity at $50 \%$ budburst was not affected by copper and hydrogen cyanamide in both seasons and zinc in the second season in comparison with the check treatment.

The obtained results were in agreement with Dhankhar (2011) found that activity of peroxidase enzyme got increased under the combined zinc and copper metals. Shulman et al., (1986) found that peroxidase activity in grapevines buds was generally unchanged by hydrogen cynanamide.

\section{Catalase (CAT) isoenzyme.}

The results of polyacrylamide gel electrophoresis on CAT isozymes under initial bud dormancy and at $50 \%$ bud burst are shown in Fig. (2). The isozyme profiles showed one band with different $R f$ for CAT in initial bud dormancy. These bands were found in samples No. 3, 6, 9 and 14 and disappeared in remaining samples (Table 9). On the other hands, CAT activity was highly increased with bud burst which appeared as achromatic zone with high intensity in all treatments, except garlic oil 2011, boric acid 2010, copper sulphate 2011, zinc sulphate 2011 and hydrogen cynamide 2011 compared with initial bud dormancy (Fig. 2 and Table 9). CAT activity at $50 \%$ budburst was not affected by all treatments in both seasons, except copper sulphate, zinc sulphate and hydrogen cyanamide in the second season. The latter treatments caused decrease in CAT activity as compared with the control. Control of the second season appeared new band at Rf 0.383 and disappeared in remaining samples in both seasons. These results were nearly similar to those obtained by Jones et al., (2000), Dhankhar (2011) and Shulman et al., (1986), they reported that copper and zinc sulphate and hydrogen cyanamide caused a reduction in catalase activity.

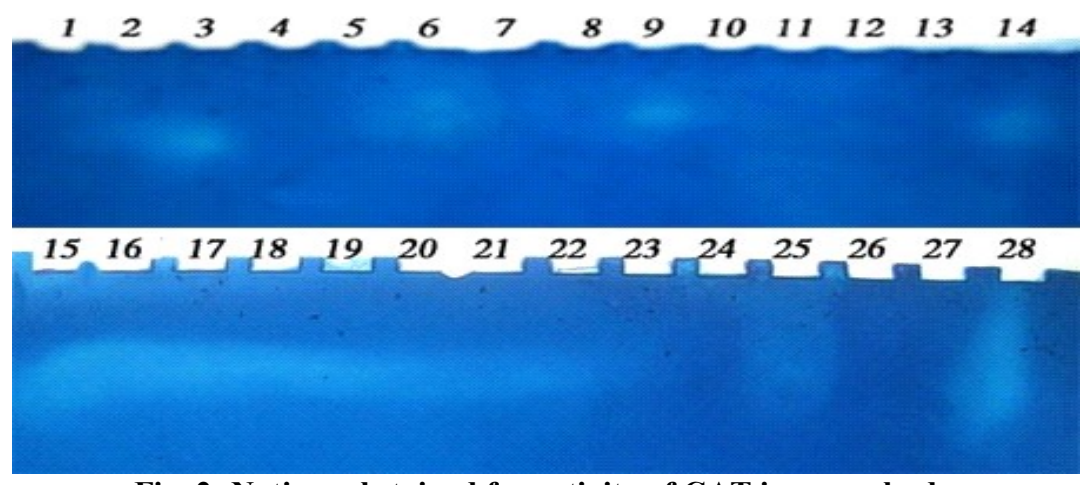

Fig. 2: Native gel stained for activity of CAT in grape buds.

Lanes 1- 14 (initial bud dormancy).

Lane 15 (Hydrogen peroxide 2010), lane 16 (Garlic oil 2010), lane 17 ( Garlic oil 2011), lane 18 (Hydrogen peroxide 2011), lane 19 (Copper sulphate 2010), lane 20 (Boric acid 2010), lane 21 (Control 2010), lane 22 (Hydrogen cyanamide 2010), lane 23 (Boric acid 2011), lane 24 (Copper sulphate 2011), lane 25 (Zinc sulphate 2010), lane 26 (Zinc sulphate 2011), lane 27 (Hydrogen cyanamide 2011) and lane 28 (Control 2011) . 
Table 9: CAT profiles of the initial grape buds dormancy and $50 \%$ bud burst in 2010 and 2011 seasons.

Samples 1- 14 (initial bud dormancy)

\begin{tabular}{|c|c|c|c|c|c|c|c|c|c|c|c|c|c|c|}
\hline$R f$ & 1 & 2 & 3 & 4 & 5 & 6 & 7 & 8 & 9 & 10 & 11 & 12 & 13 & 14 \\
\hline 0.508 & & & & & & + & & & + & & & & & \\
\hline 0.595 & & & & & & & & & & & & & & + \\
\hline 0.616 & & & + & & & & & & & & & & & \\
\hline
\end{tabular}

Table 9: Continued. 15-28 50\% bud burst

\begin{tabular}{lllllllllllllll}
\hline $\boldsymbol{R} \boldsymbol{f}$ & $\mathbf{1 5}$ & $\mathbf{1 6}$ & $\mathbf{1 7}$ & $\mathbf{1 8}$ & $\mathbf{1 9}$ & $\mathbf{2 0}$ & $\mathbf{2 1}$ & $\mathbf{2 2}$ & $\mathbf{2 3}$ & $\mathbf{2 4}$ & $\mathbf{2 5}$ & $\mathbf{2 6}$ & $\mathbf{2 7}$ & $\mathbf{2 8}$ \\
\hline 0.383 & & & & & & & & & & & & & & + \\
\hline 0.595 & + & + & + & + & + & + & + & + & + & & + & & & \\
\hline
\end{tabular}

$+=$ Presence of band.

15 (Hydrogen peroxide 2010) - 16 (Garlic oil 2010) - 17 (Garlic oil 2011) - 18 ( Hydrogen peroxide 2011) - 19 (Copper sulphate2010) - 20 (Boric acid 2010) - 21 (Control 2010) - 22 (Hydrogen cyanamide 2010) - 23(Boric acid 2011) 24 (Copper sulphate 2011) - 25 (Zinc sulphate2010) - 26 (Zinc sulphate 2011) - 27 (Hydrogen cyanamide 2011) 28 (Control 2011).

\section{ACKNOWLEDGMENT}

I would like to express my great thanks to soul of my father, soul of my friend Dr.Sameh Ezzt, Researcher, City of Scientific Research and Technology Applications and soul of Prof. Dr.Mohamoud Tahoun, Professor of Dairy Science and Technology Department, Faculty of Agriculture, Alexandria University for support and achievement of the study.

\section{REFERENCES}

Abbas, M. T., Melook , A.M . and El Abassy, U.K. (1999). Effect of some chemicals treatments during dormant season on growth and fruiting of Thompson Seedless grapevine. Agric . Sci . Mansoura Univ.Vol 24(1).

Abd El Hameed, A. Gobara and M. Attia (2007). Effect of some micronutrients, gibberellic and ascorbic acid on growth, yield and quality of White banaty seedless grapevines. African Crop Science Conference Proceeding. Vol 8. pp. 547- 553.

Abd el-Latife, A. M. R .(2007). Effect of some organic and biological treatments on Flame seedless grapevine. Ph.D. Thesis. Cairo University

Abd El- Rzek, E ., M .M.M. Abd El-Migeed and N. Abdel - Hamid (2011a). Effect of spraying garlic extract and olive oil on flowering behavior, yield and fruit quality of "Canino" apricot trees. American - Eurasian . J . Agri . and Enviro . Sci . 11(6): 776-781.

Abd El-Razek, E., D. Treutter, M.M.S.Saleh, M.ElShammaa, A.A.Foud and N.Abdel-Hamid (2011b). Effect of nitrogen and potassium fertilization on productively and fruit quality of "Crimson seedless" grape.Agri.Biol.J.N.Am. 2(2): 330-340.
Abd El-Razek, E., M.M. Abd El-Migeed and N. Abdel- Hamid (2013). Response of "Le conte " pear tress to garlic extract and GA3 as bud break dormancy agents. Middle- East Journal of Scientific Research 14(11): 1407 - 1413.

Abd El-Wadoud, M. Z. (2010). Studies on using some natural extracts in breaking bud dormancy of grapes to reduce the pollution of chemical treatments. Ph.D. Thesis. Institute of Enviromental studies and Research. Ain Shams University.

Abdel Hameed, M.W. (1997). Effect of Dormex on "Roomy Red" grapevine. Hort. Science 32(3).

Ahmed, A . K . and El-Sese ,A.M.A . (2004). Effect of some chemical compounds and growth regulators on regularity of bud break, flowering and fruiting of Red Roomy grapevine. Assiut. J. of. Agri. Sci., 35(2):165181 .

Aktas, H., K. Abak , L. Oztirk and I. Cakmak (2006). The effect of zinc on growth and shoot concentration of sodium and potassium in pepper plants under salinity stress. Turk. J. Agric. 30: 407-412.

Al-Shoffe, Y.S. (2005) Effect of some supplementary refrigeration treatments on storagability of grapes. M.Sc. Thesis, Fac. Agri, Ain Shams Univ. Egypt.

Attia, M. F. (1998). Effect of foliar nutrition, different vine -bud-load and spur length on some vegetative and fruiting characters of Red Roomy grapevines. M.Sc. Thesis. Fac. of Agric., Minia Univ ., Egypt.

A.O.A.C., 1990. Association of Official Analytical Chemists Edited by S. Williams, Association of Official, Analytical Chemists.

Dhankhar, R. (2011). Zinc and copper induced changes in physiological characteristics of Vignamungo. J. Environ . Biol . 32 , 747 - 751. 
Diaz, D. H., A. Alvarez and J. Sandoval (1987). Cultural and chemical practices to induce uniform budbreak of peach and apple under warm climates in mexico. ActaHorticulturae 199: 129-136.

Dokoozlian, N. K and L. E. Williams (1995). Chilling exposure and hydrogen cyanamide interact in breaking dormancy of grape buds. HortScience 30(6): 1244-1247

El-Halaby, E.H.S. (2006). Trials for producing early with high quality "Superior seedless" M.Sc. Thesis Fac. of Agri. Minia. Univ. Egypt.

Eshghi, S., M. Rahemi and A. Karami (2010) Overcoming winter rest of grapevine grown in subtropical regions using dormancy-breaking agents . Iran Agricultural Research, 29, No. 12.

Faissal, F . A ., M . A . Ahmed and F . El-Morsy (1997) Yield and quality of " Banaty" grapes in response to spraying iron and zinc. HortScience, Vol 32(3).

Farag, K.M. (2006). Degreening and reducing berry shatter of Thompson seedless grapes by using safe agricultural chemicals. Journal of Agriculture and Enviromental Sciences. Vol 5(2): $634-641$.

Fulford, R. M. (1970). The effect of chemical defoliation on the development of apple spurs . Annals of Botany. Vol 34 . 5: 1079-1088.

George , A . P. and R . J . Nissen (1990). Effect of hydrogen cyanamide on yield, growth and dormancy release of table grapes in subtropical Australia . Acta Hort. 279 : 427-436.

Gonzalez-Sanjose, M.L., C. Diez (1992) Relationship between anthocyanins and sugars during the ripening of grape berries . Food . Chem.43, 193-197.

Hanafy, A . A, M. K. Khalil, A . M . Abd ElRahman and N. A. M . Hamed (2012) Effect of zinc, tryptophan and indol acetic acid on growth, yield and chemical composition of Valencia orange trees. Journal of Applied Sciences Research , 8(2): 901-914.

Hassan, A. Y. M. (2008). Attempts for breaking endodormancy in Red Roomy grapevines. M.Sc. Thesis, Fac. of Agri., Minia Univ., Egypt.

Husia, C. L.; B. S. Luh, and C. D. Chichester, (1965). Anthocyanin in free stone peach. J. Food Science, 30: 5-12.

Jana, B.R. and B.Das (2013). Effect of dormancy breaking chemicals on flowering, fruit set and quality in Asian pear. African Journal of Agricultural Research . Vol.9 (1), pp.56-60 .

Jones, M., R. Fosbery and D. Taylor (2000). Advanced Sciences - Biology I.Cambridge University Press.P.272.
Jordao, A.M. and A.C. Correia (2012). Relationship between antioxidant capacity, proanthocyanidin and anthocyanin content during grape maturation of TourigaNacional and TintaRoriz grape varieties . S. Afr.J. Enol . Vitic . 33, No.2.

Kim, W. and S. Jeong(2001). Research trends and commercial uses of plant growth regulators on grapes and peaches. Korean J . of Hort . Sci . and Tech . 19(2): 222-231.

Kubota, N ., M. A. Mattheurs, T. Takahagi and W. M. Kliewer (2000). Bud break with garlic prepartions. Am. J. Enol. Vitic., Vol .51, No.4.

Kuroda, H.S.S.Sagisaka and H.Sugiura (2005). Effect of hydrogen peroxide on breaking endodormancy in flower buds of Japanese pear (Pyrus pyrifolia Nakai). J.Japan.Soc.Hort.Sci. , 74, 255-257.

Lang , A.(1983). Turgor-related translocation. Plant, Cell and Envir.6:683-689.

Lavee, S., Y. Shulman and G. Nir. (1984) The effect of cyanamide on budbreak of grapevines Vitis vinifera L., p. 17-29. In: R. J. Weaver (ed). Proceedings of bud dormancy in grapevine: potential and practical uses of hydrogen cyanamide on grapevine. Univ. of California, Davis .

Marschner, H. (1995) Mineral Nutrition of Higher Plants. $2^{\text {nd }}$ Ed. Academic Press. NewYork.P.889

McColl, C. R. (1986) Cyanamide advances the maturity of table grapes in central Australia Austral. J . Expt . Agri . 26: 505-509 .

Nijjar, G. S. (1985). Nutrition of Fruit Trees in Fertilizers and Manures (Eds-Kumar, U. R), Kilyani press, New Delhi, India, 206-234 pp.

Nikkhuh, R . H . Nafar, S. Nafar, S . Rastgoo and M. Dorostkar (2013). Effect of foliar application of boron and zinc on qualitative and quantitative fruit characteristics of grapevine. International Journal of Agriculture and Crop Sciences, 13(6): 485-492 .

OR, E, G. Nir and I. Vilozny (1999) Timing of hydrogen cyanamide application to grapevine buds . Vitis . 38(1), 1-6.

Powell, A.A. (1997). The effects of Dormex on replacing lack of chilling in kiwifruit. Retrieved from http: // www. Aces . edu.

Rogiers, S. Y. , D. H . Greer, J . M . Hatfield, B. A. Orchard and M. Keller (2006) Mineral sinks within ripening grape berries. Vitis $\mathbf{4 5 ( 3 )}, 115$ 123.

Settimi, L., F. Davanzo, G. Miceli, D. Richmond and G.M. Calvert (2005) Update: Hydrogen Cyanamide-related IInesses-Italy, 2002-2004. Morbidity and Mortality Weekly Report, Atlanta, 54, p.405-408. 
Shaddad, A.M.G.(2010). Physiological studies on breaking bud dormancy of grapes. Ph.D. Thesis, Fac. of Agric., Ain Shams Univ., Egypt.

Shulman, Y., Nir, G. and Lavee, S.(1986). Oxidative processes in bud dormancy and the use of hydrogen cyanamide in breaking dormancy . Acta Hort . 179: 141-148.

Smith, R. (2006). Effect of boron fertilizer applications on grapevine pruning wounds on budbreak, boron tissue levels and vine yield. UC Cooperative Extension, Sonoma County Grape Day.
Snedecor, G.W. and W.G. Cochran, 1980. Statistical Methods. Oix and J.B.Pud . Com. 6 th Edition.

Stegemann, H., A.M.R. Afify, K.R.F. Hussein, 1985. Cultivar identification of dates (Phoenix dactylifera) by protein patterns. Second International Symposium of Biochemical Approaches to Identification of Cultivars. Braunschweing, West Germany, pp 44.

Tourky, M. N; S. S. El-Shahat and M. H. Rizk,.(1995). Effect of Dormex on fruit set, quality and storage life of Thompson Seedless grapes (Banati grapes).J. Agric., Mansoura Univ.,20(12): 5139-5151.

Woodbury W., Spencer A.K., Stahmann. M.A.1971. An improved procedure using ferricyanide for detecting catalase isozymes. Analytical Biochemistry 44, 301-305 


\section{الملخص العربي}

\section{ايجاد بائل رخيصة وأمنة لسيناميد الهيدرجين على العنب صنف الفليم سيللس}

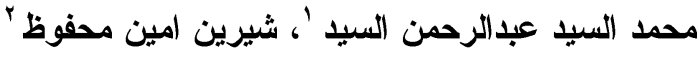

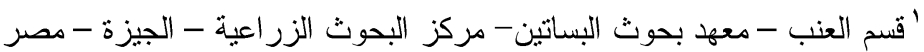

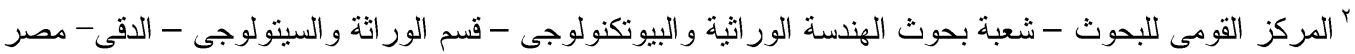

تم تتفيذ هذة التجربة لدراسة تاثثر بدائل امنة مقارنة بسيناميد الهيدروجين على كسر سكون البراعم فى صنف عنب الفليم سيدلس. اشتملت التجربة على معاملات الرش الاثية: كنترول وزيت الثوم وفوق اكسيد الهيدروجين وكبريتات النحاس وكبريتات الزنك وحمض البوريك وسيناميد الهيدروجين فى الاسبو ع الثانى من بناير ـ أدت جميع

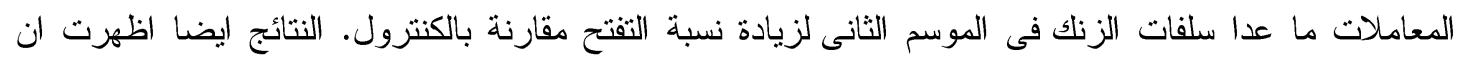
كبريتات النحاس وسيناميد الميدروجين ادت الى زيادة معنوية فى نسبة تقتح البر اعم مقارنة بباقى المعاملات في كلا

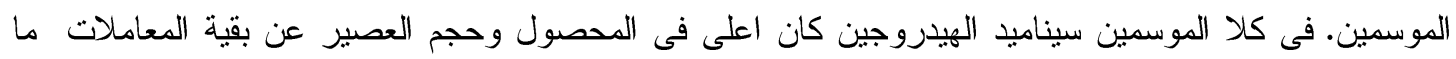

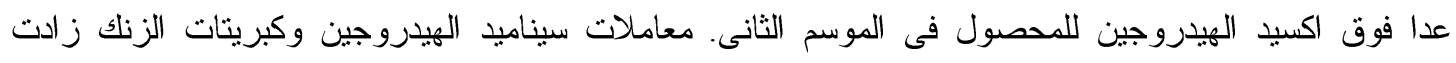
معنويا من وزن العنقود فى الموسم الثانى فقط. وزن وحجم 100حبة زادت معنويا بكبريتات النحاس و الزناتك وسيناميد

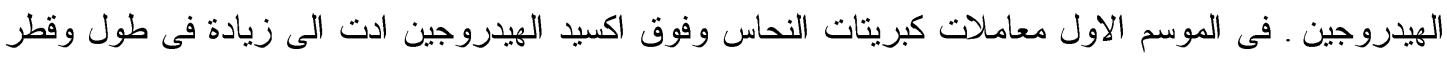

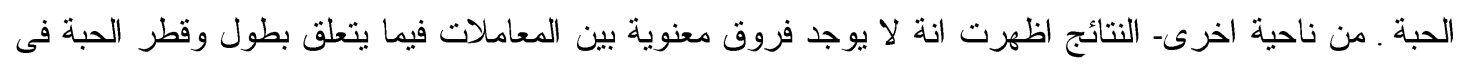

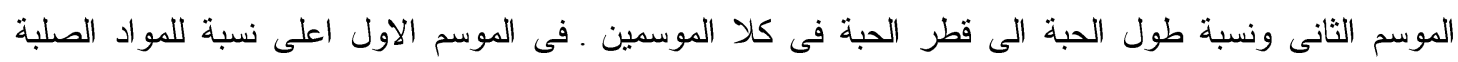

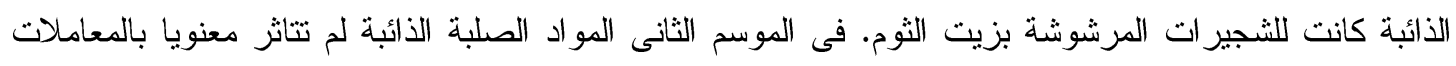
المختلفة . النتائج اظهرت ان كبريتات الزنك و النحاس وزيت الثوم خفض الحموضة لتونة معنويا فى الموسم الثانى ـ النتائج في كلا الموسمين الثارت الى ان زيت الثوم وكبريتات الزنك و النحاس تؤدى الى زيادة نسبة المو اد الصلبة الذائبة

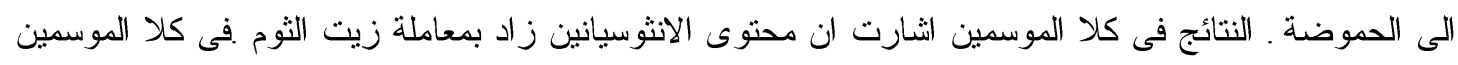
زيت الثوم وسيناميد الهيدروجين زاد معنويا من طول الفرخ. فوق اكسيد الهيدروجين ادى الى زيادة فى النسبة

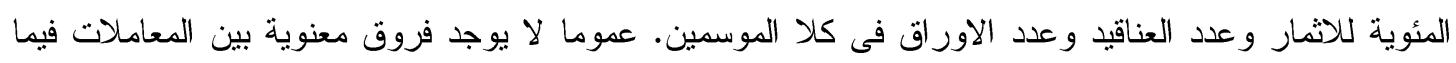
يتعلق بنشاط البيروكسيديز . نشاط الكتاليز زاد بشكل عالى مع تفتح البر اعم فى كل المعاملات معات ما عدا معاملات

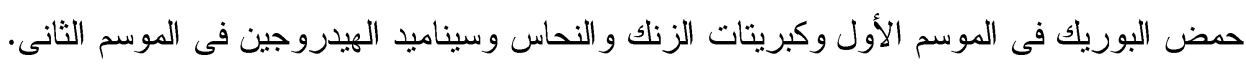

